\title{
DISTRIBUSI PIGMEN KAROTENOID PADA KEPITING Grapsus sp DENGAN MENGGUNAKAN METODE KROMATOGRAFI LAPIS TIPIS
}

\author{
(Distribution of Carotenoid Pigments in Grapsus sp Crab Using Thin Layer \\ Chromatography Method)
}

\section{M.Ridha Abdi Abdullah ${ }^{1 *}$, Darus Saadah J. Paransa1, Desy M.H. Mantiri ${ }^{1}$, Esther Deilayani Angkow ${ }^{1}$, Ping A. Angmalisang ${ }^{1}$, Joppy D. Mudeng ${ }^{2}$}

1. Program Studi Ilmu Kelautan, Fakultas Perikanan dan Ilmu Kelautan, Universitas Sam Ratulangi, Manado.

2. Program Studi Budidaya Perairan, Fakultas Perikanan dan Ilmu Kelautan, Universitas Sam Ratulangi, Manado.

*e-mail : ridhaabdullah637@gmail.com

Crustaceans are marine organisms with their own uniqueness, because their colorful visualization and recycling of trees can change skin. The specificity of the color of the crustaceans also attracts attention when cooking, which changes color to red. This phenomenon occurs because of the dyes contained by crustaceans and known as pigments.In general marine organisms referred to as crustaceans contain carotenoid pigments of various types and types. Carotenoid pigments are natural dyes (biochromes) commonly found in crustaceans. In previous studies showed that the determination of the type of pigment can be done using Thin Layer Chromatography (TLC) method.TLC is a fast and easy way to separate compounds in a sample. This method makes it easy for small-scale analysis because it only requires very few ingredients and the time required is very short, therefore to find out the distribution of carotenoid pigments in Grapsus sp crabs in this study using the TLC method. The results obtained from this study found that the distribution of carotenoid pigments in crabs Female sperm capsules were distributed in the type of pigment $\beta$-carotene, $\beta$-cryptoxanthine, astaxanthine and astacene type pigment, which were distributed to the carapace, epidermal layer, hepatopancreas and gonads of Grapsus sp. crabs.

Keywords: Carotenoids, Thin Layer Chromatography, Grapsus sp

Krustasea merupakan organisme laut dengan keunikan tersendiri, karena visualisasinya yang beraneka warna dan dalam daur hidupnya organisme ini dapat berganti kulit. Kekhasan warna yang dimiliki oleh krustasea juga menarik perhatian pada saat dimasak yakni berubah warna menjadi merah. Fenomena ini terjadi karena adanya zat warna yang dikandung oleh krustasea dan dikenal sebagai pigmen karotenoid. Pada umumnya organisme laut termaksud krustasea memiliki kandungan pigmen karotenoid dengan jenis dan tipe yang beragam. Pigmen karotenoid merupakan pewarna alami (biokrom) yang umumnya terdapat pada krustasea. Pada penelitianpenelitian sebelumnya menunjukkan bahwa penentuan jenis pigmen dapat dilakukan dengan menggunakan metode Kromatografi Lapis Tipis (KLT). KLT merupakan cara cepat dan mudah untuk pemisahan senyawa pada suatu sampel berdasarkan polaritas. Metode ini memudahkan untuk analisis skala kecil karena hanya memerlukan bahan-bahan yang relatif sedikit dan juga waktu yang cukup singkat, maka dari itu untuk mengetahui distribusi pigmen karotenoid pada kepiting Grapsus sp dalam penelitian ini menggunakan metode KLT. Hasil yang diperoleh dari penelitian ini ditemukan bahwa distribusi pigmen karotenoid pada kepiting Grapsus sp betina adalah jenis pigmen $\beta$-karoten, $\beta$-kriptoksantin, astaksantin dan pigmen tipe astasen, yang terdistribusi pada organ karapas, lapisan epidermis, hepatopankreas dan gonad dari kepiting Grapsus sp.

Kata kunci : Karotenoid, Kromatografi Lapis Tipis, Grapsus sp 


\section{PENDAHULUAN}

Krustasea merupakan organism laut dengan keunikan tersendiri, karena visualisasinya yang memiliki warna yang menarik dan siklus hidup organism ini dapat berganti kulit. Kekhasan warna yang dimiliki oleh cangkang krustasea akan berubah warna menjadi merah pada saat dimasak. Perubahan warna yang tampak pada saat pemanasan, disebabkan ikatan antara senyawa protein dan karotenoid mengalami proses denaturasi sehingga terputus antara senyawa protein dan senyawa karotenoid. Menurut Mantiri et al. (2004) karotenoid adalah pigmen utama yang terdapat pada lapisan epidermis dan karapas krustasea adalah pigmen astaksantin yang berwarna merah. Pigmen astaxantin ditemukan pada krustasea Homarus gammarus sejak stadium embrio sampai larva, (Mantiri et al., 1996). Ableson and Simon (1992) menyatakan bahwa krustasea memiliki kandungan pigmen karotenoid yang terdiri dari golongan karoten dan xantofil, xantofil memiliki jenis pigmen yang beragam. Hasil penelitian Paransa et al. (2002), menemukan pigmen jenis $\beta$-Karoten pada ekstrak pigmen total kepiting Grapsus albolineatus (Lamarck) betina yang ditangkap dari pesisir pantai Kalasey. Selanjutnya pada hasil penelitian Paransa (2005), ekstrak total organ karapas dari sampel kepiting G. albolineatus (Lamarck) Jantan yang ditangkap pada pesisir pantai Malalayang, Kota Manado mengandung jenis pigmen astaksantin. Thamin et al. (2006) menemukan pigmen jenis Astaksantin Diester, Astaksantin Monoester dan pigmen Astaksantin Bebas pada ekstrak pigmen total organ karapas dari kepiting $G$. albolineatus (Lamarck) jantan dan telah ditemukan pada lobste $H$. gammarus (Mantiri et al., 1995). Pada hasil penelitian di atas, penentuan jenis pigmen pada tersebut di atas, pemisahan jenis pigmen menggunakan metode Kromatografi Lapis Tipis (KLT) berdasarkan polaritas. Menurut Stahl (1985), metode KLT merupakan cara cepat dan mudah untuk pemisahan senyawa pada suatu sampel. Metode ini memudahkan untuk analisis skala kecil karena hanya memerlukan bahan-bahan yang sangat sedikit dan waktu yang dibutuhkan sangat singkat, oleh karena itu, untuk mengetahui distribusi pigmen karotenoid pada kepiting Grapsus sp dalam penelitian ini menggunakan metode Kromatografi Lapis Tipis.

\section{METODE PENELITIAN}

Lokasi yang dijadikan sebagai tempat pengambilan sampel adalah perairan berbatu Desa Manggatasik Kecamatan Tombariri Kabupaten Minahasa Propinsi Sulawesi Utara. Sampel yang telah diperoleh dari lokasi penelitian kemudian dibawa ke laboratorium Bioteknologi Kelautan Fakultas Perikanan dan IImu Kelautan UNSRAT Manado untuk di lakukan penanganan sampel yang meliputi identifikasi sampel, ekstraksi, analisis jenis pigmen dengan metode KLT, identifikasi jenis pigmen, serta pengamatan jenis pigmen yang teridistribusi pada tiap organ kepiting Grapsus sp.

\section{Penanganan sampel}

Pengambilan sampel kepiting Grapsus sp. dilakukan pada malam hari dengan mengunakan alat bantu penerangan berupa senter, dan wadah untuk mengumpulkan sampel. Pengambilan sampel dilakukan secara langsung dengan tangan. Proses selanjutnya adalah identifikasi sampel berdasarkan panduan (Majchacheep 1989). Sampel kepiting Grapsus sp kemudian dibedah untuk diambil organ dalam seperti lapisan epidermis, hepatopankreas, gonad, dan hemocyanin, serta organ luar seperti karapas. Selanjutnya dilakukan ekstaksi pada tiap organ dengan larutan organik.

\section{Ekstaksi}

Proses ekstraksi yang dilakukan menurut Mantiri, (1997). Setiap organ kepiting yang diperoleh digerus sampai jaringan berwarna putih. Khusus pada organ karapas, direndam dengan HCL selama tiga menit. Masing masing organ yang telah digerus, ditambahkan larutan asetone sebanyak $10 \mathrm{ml}$, kemudian disaring dan ditampung ke dalam labu pemisah. Kemudian ditambahkan larutan petrolium eter, diamkan sampai terjadi pemisahan. Setelah terjadi pemisahan, lapisan bagian 
bawah dibuang dan lapisan bagian atas diambil sebagai ekstrak pigmen total.

\section{Analisi Jenis Pigmen}

Pigmen total pada tiap organ kemudian di analisis jenis pigmen berdasarkan polaritas menggunakan metode pemisahan Kromatografi Lapis Tipis dengan mengguanakan fase diam berupa plat silica gel Tipe 60 dan fase gerak (larutan pengembang) $\mathrm{PE}$ : Aseton dengan perbandingan $80: 20$ (Mantiri, et al., 1995). Plat silika gel sebagai fase diam dipanaskan terlebih dahulu selama 24 jam. Selanjutnya dibuat garis horizontal untuk spot awal, serta garis akhir sebaga batas larutan pengembang naik. Sampel pigmen total ditotolkan pada garis awal. Setelah sampel ditotolkan, masukan kromatogram ke dalam camber yang berisi larutan pengembang PE: Aseton (80:20). Setelah larutan pengembang naik sampai ke batas akhir, kemudian angkat plat kromatoram dari camber. Apabila sudah terjadi pemisahan di atas plat kromatogram, hitung nilai Rf (Retention factor) untuk mengetahui batas migrasi pigmen. Perhitungan nilai Rf berdasarkan perhitungan matematis (Rohman 2009). Hasil fraksi yang terbentuk di atas plat kromatogram diisolasi berdasarkan lapisan yang terbentuk dan dilarutkan dengan aseton sebanyak $2 \mathrm{ml}$. Hasil isolasi fraksifraksi tersebut, kemudian diserap dengan spektrofotometer pada panjang gelombang 380-550 nm. Bentuk kurva dan serapan maksimum pada tiap fraksi yang diperoleh dapat menunjukan jenis pigmennya berdasarkan buku panduan Britton et al. (1995) dan Britton et al. (2004). Distribusi pigmen karotenoid dari organ-organ Grapsus sp. dapat dilihat pada dokumentasi plat kromatogram (Gambar 1).

\section{HASIL DAN PEMBAHASAN}

Sampel kepiting yang ditangkap di pesisir pantai Mangatasik Kabupaten Minahasa, Provinsi Sulawesi Utara memiliki ciri-ciri pada karapas berbentuk konveks sirkular dengan ukuran lebar $4 \mathrm{~cm}$ dan lebih lebar dari pada panjang karapas. Pada bagian anterior di antara mata terbagi atas empat lobes.Pada pasangan kaki jalan yang pertama adalah yang paling pendek dengan barisan setae yang tampak pada batas ventral dari kaki jalannya. Pada permukaan dorsal tampak garis longitudinal berwarna ungu kemerahan. Ciri ciri sampel seperti ini menurut Majchacheep (1989), teridentifikasi sebagai Grapsus sp. (Lamarck) dan berjenis kelamin betina. Untuk mengetahui distribusi pigmen dari masing-masing organ pada tiap organ kepiting Grapsus sp. (Lamarck) betina, selanjutnya diekstraksi untuk diperoleh pigmen total, kemudian difraksinasi dengan metode Kromatografi Lapis Tipis larutan pengembang PE : Aseton perbandingan (80:20).

\section{Analisis Jenis Pigmen pada Ekstrak Pigmen Total Organ Kepiting Grapsus sp. (Lamarck) Betina.}

Hasil pemisahan pigmen dengan KLT pada tiap organ kepiting Grapsus sp. (Lamarck) betina yang menghasilkan 7 fraksi (Gambar 1). Hasil serapan maksimum spektrofotometer dapat dilihat pada Gambar 2.

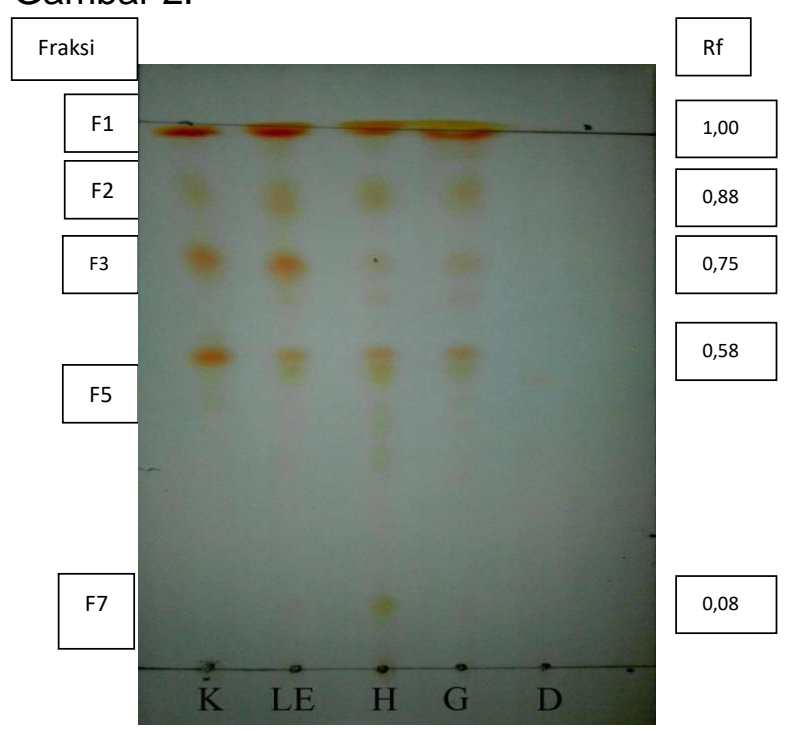

Gambar 1. Kromatogram pemisahan pigmen pada ekstrak tiap organ kepiting Grapsus sp. (Lamarck) betina. 
Fraksi 1 pigmen $\beta$ - Karoten.

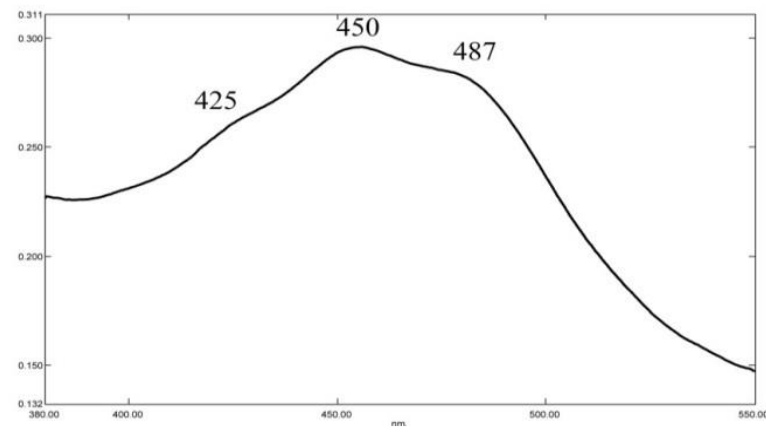

Panjang Gelombang (nm)

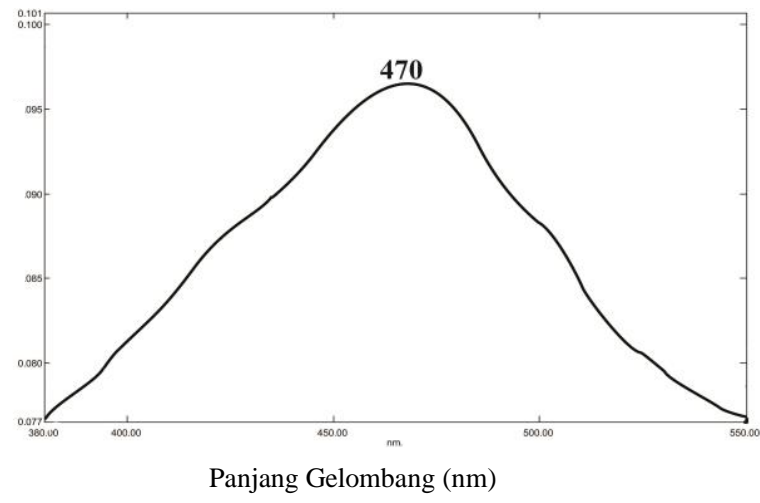

Fraksi 3 pigmen Akstaksantin
Fraksi 2 pigmen $\beta$-Kriptoksantin.

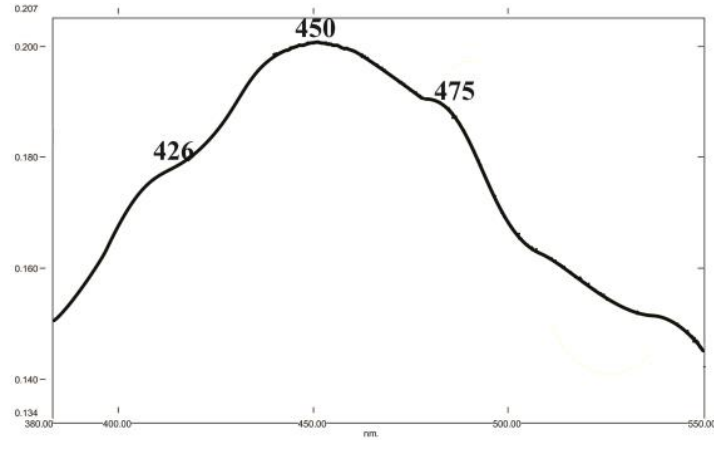

Paniang Gelombang (nm)

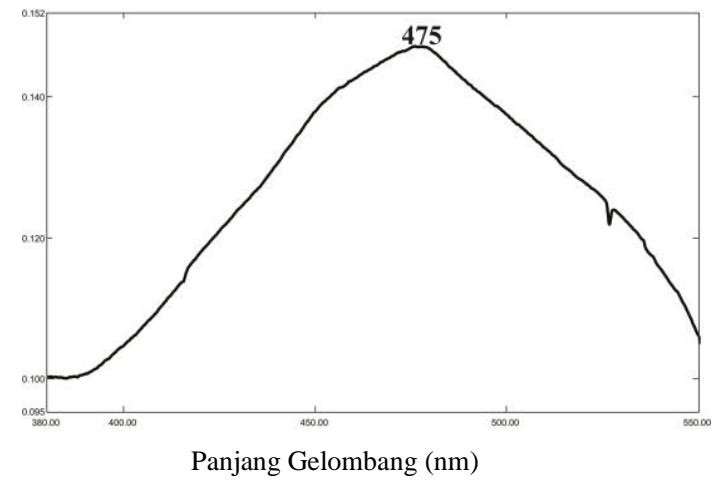

Fraksi 5 pigmen Astasen

Gambar 2. Hasil serapan maksimum spektrofotometer fraksi 1 - fraksi 5 yang teridentifikasi.

Kromatogram pada Gambar 1. menunjukan terjadinya pemisahan senyawa dari ektrak pigmen total. Hasil migrasi membentuk fraksi-fraksi berdasarkan polaritas senyawa. Menurut Landrum (2010), pigmen karotenoid merupakan senyawa yang bersifat non polar dari hasil ekstrak pelarut organik (metanol, etanol, aseton). Perbedaan polaritas antara plat silika gel dengan senyawa pigmen akan megakibatkan migrasi senyawa pigmen naik ke atas plat silika gel. Hasil serapan maksimum spektrofotometer yang membentuk kurva dengan satu atau lebih puncak, digunakan untuk identifikasi jenis pigmen (Britton et al., 1995). Seperti pada (Gambar 2) di atas, menunjukan puncak pada kurva dapat digunakan untuk identifikasi jenis pigmen.

\section{Fraksi 1}

Pada fraksi 1 pada plat silika gel, berwarna oranye, dengan nilai $R f 1,00$ dan hasil serapan maksimum spektrofotometer pada panjang gelombang 425-450-487 nm (Gambar 2). Hasil kromatogram dan hasil serapan maksimum spektrofotometer menurut Britton et al. (1995) teridentifikasi sebagai jenis pigmen $\beta$-Karoten. Makalalag et al. (2017) juga menemukan pigmen jenis $\beta$-Karoten pada fraksi 1 dari ekstrak pigmen total kepiting G.albolineatus (Lamarck) betina yang ditangkap dari perairan Desa Tanawangko. Britton et al. (2004) menyatakan bahwa $\beta$-Karoten secara umum ditemukan pada fraksi 1, hal ini dikarenakan $\beta$-Karoten memiliki sifat non polar sehingga mampu bermigrasi naik ke atas dari plat silika gel yang bersifat polar. 


\section{Fraksi 2}

Fraksi 2 (Rf 0.88) berwarna oranye di atas plat silika gel memiliki puncak serapan maksimum spektrofotometer pada panjang gelombang 426, 450, $475 \mathrm{~nm}$. Menurut Britton et al. (1995). hasil dari pemisahan KLT dan serapan maksimum spektrofotometer teridentifikasi sebagai jenis pigmen $\beta$-Kriptosantin. Landrum (2010) menyatakan bahwa $\beta$-Kriptosantin masih berkaitan dengan $\beta$-Karoten, karena metabolisme pigmen $\beta$-Karoten menerima gugus hidroksi pada siklik sebelah kiri sehingga terbentuklah pigmen $\beta$ Kriptosantin.

\section{Fraksi 3}

Fraksi ke-3 tampak berwarna kemerahan di atas plat silika gel dengan nilai migrasi senyawa pada $\mathrm{Rf} 0,75$ dan hasil serapan spektrofotometer terbentuk satu puncak pada panjang gelombang $470 \mathrm{~nm}$. Menurut Britton et al. (1995) pada panjang gelombang tersebut teridentifikasi sebagai jenis pigmen Astaksantin.

Hasil penelitian Thamin et al. (2006), pada ekstrak pigmen total dari organ karapas dan Lapisan epidermis kepiting $G$. albolineatus jantan dari pesisir pantai Malalayang Dua, Kota Manado teridentifikasi mengandung pigmen astaksantin monoester, astaksantin diester dan astaksantin bebas. Paransa (2005) jenis pigmen astaksantin di temukan pada kepiting G.albolinetaus jantan. Pigmen astaksantin ditemukan dari hasil pemisahan jenis pigmen dengan menggunakan dua jenis pengembang yaitu Petroleum eter dan Aseton dengan perbandingan 80:20 dan perbandingan 95:5. Pada hasil penelitian Paransa and Abdullah (2007), pigmen astaksantin ditemukan pada organ karapas, lapisan edipermis, hepatopankreas, hemocyanin dan gonad dari kepiting bakau Scylla serrata (forkal,1775) jantan yang di tangkap pada pesisir perairan Likupang. Menurut Landrum (2010), astaksantin merupakan jenis pigmen mayor yang terdapat pada krustasea terutama pada bagian karapas dan lapisan epidermis. Selain kepiting, kandungan pigmen akstaksantin juga terdapat pada alga, seperti penelitian hasil Fretes et al. (2012), menemukan kandungan pigmen astaksantin pada alga merah spesies Kappaphycus alvarezii.

\section{Fraksi 5}

Fraksi 5 (Rf) 0,58 berwarna orange di atas plat silika gel, dan memiliki hasil serapan maksimum spektrofotometer membentuk 1 puncak pada panjang gelombang $475 \mathrm{~nm}$ fraksi ke lima teidentifikasi sebagai pigmen Tipe astacen. Hasil analisis jenis pigmen dengan metode Kromatografi Lapis Tipis pada fraksi ke 5 ini serupa dengan penelitian Makalalag et al. (2017), dimana jenis pigmen astasen ditemukan pada fraksi ke 3 dengan serapan maksimum spektrofotometer pada panjang gelombang $448 \mathrm{~nm}$. Penelitian yang dilakukan Makalalag et al. (2017) mengunakan larutan pengembang yang bersifat non polar yaitu PE dan Aseton dengan perbandingan (95:5) dan berbeda dengan pengembang yang digunakan pada penelitian ini. Hasil penelitian Waworuntu (2003) juga pigmen tipe Astasen pada fraksi ke 3 ditemukan dari hasil ekstrak saponifikasi.

\section{Distribusi Pigmen Karotenoid pada Tiap Organ Kepiting Grapsus sp. (Lamarck) Betina}

Untuk mengetahui distribusi pigmen pada tiap organ karapas $(\mathrm{K})$, lapisan epidsampel (LE), hepatopankreas (H), gonad (G), dan hemocyanin (D) kepiting Grapsus sp (Lamarck) betina dapat dilihat dari fraksi yang terbentuk pada plat kromatogram (Gambar 1). Pada tiap organ yang terbentuk fraksi adalah organ yang terdistribusi pigmen karotenoid.

Jenis pigmen yang terkandung pada ekstrak Pigmen Total kepiting tiap organ kepiting Grapsus sp (Lamarck) betina dari pesisir perairan pantai yang berbatu di desa Manggatasik Kabupaten Minahasa Sulawesi Utara terdistribusi pada organ karapas (K), lapisan epidermis (LE), hepatopankreas $(H)$ dan gonad $(G)$. Distribusi jenis pigmen dengan membentuk satu jalur metabolisme tampak pada Tabel 1 di bawah ini. 
Tabel 1. Distribusi pigmen pada tiap organ dari kepiting Grapsus sp (Lamarck) betina.

\begin{tabular}{|c|c|c|c|c|c|c|}
\hline StrukturPigmen & Jenis Pigmen & \multicolumn{5}{|c|}{$\begin{array}{c}\text { Organ yang } \\
\text { Terdistribusi Pigmen }\end{array}$} \\
\hline & & $\mathrm{K}$ & LE & $\mathbf{H}$ & $\mathbf{G}$ & D \\
\hline 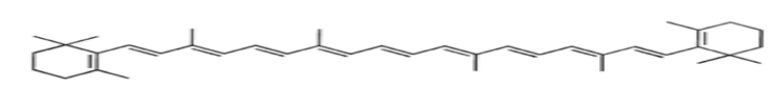 & $\beta$-karoten & $*$ & $*$ & $*$ & $*$ & \\
\hline 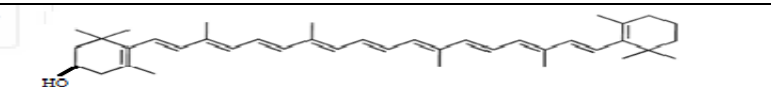 & $\beta$-kriptosantin & $*$ & $*$ & $*$ & $*$ & \\
\hline 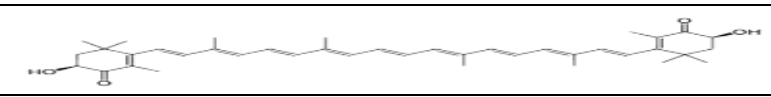 & Astaksantin & $*$ & $*$ & $*$ & $*$ & \\
\hline 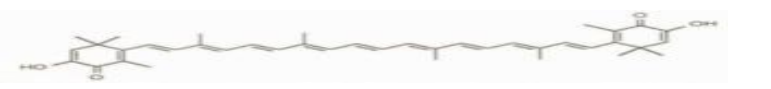 & Tipe astacen & $*$ & $*$ & $*$ & $*$ & \\
\hline
\end{tabular}

Berdasarkan tabel 1, pada organ karapas, lapisan epidermis, hepatopankreas dan gonad terdistribusi pigmen jenis $\beta$ karoten, $\beta$-kriptosantin, astaksantin dan Tipe astacen. Pigmen $\beta$-karoten menerima gugus hidroksil pada satu sisinya sehingga terbentuk pigmen $\beta$-kriptoksantin. Pigmen kriptoksantin terdapat pada organ yang sama dengan jenis pigmen $\beta$-karoten. Pigmen $\beta$-kriptoksantin menerima gugus karbonil pada rantai siklik sebelah kiri dan pada rantai siklik sebelah kanan menerima gugus karbonil dan gugus hiroksil secara bersamaan sehingga terbentuk pigmen mayor astaksantin. Terbentuknya pigmen astacen yang dikandung oleh spesies yang digunakan pada penelitian ini, dimana ikatan rangkap pada rantai siklik mengalami perpindahan dalam proses metabolismenya. Pada organ hemocyanin tidak ditemukan fraksi, hal ini diasumsikan bahwa kandungan pigmen telah tersebar pada organ organ yang membutuhkan jenis pigmennya (Britton et al., 1995).

\section{KESIMPULAN}

Dalam penelitian ini dapat disimpulkan bahwa Jenis pigmen yang teridentifikasi pada kepiting Grapsus sp. (Lamarck) betina dengan metode KLT ditemukan jenis pigmen $\beta$-karoten, $\beta$ - kriptoksantin, astaksantin dan pigmen astasen. Distribusi jenis pigmen $\beta$-karoten, $\beta$-kriptosantin, astaksantin dan astasen terdistribusi pada karapas, lapisan epidermis, hepatopankreas, dan gonad.

\section{DAFTAR PUSTAKA}

Abelson, N. J., Simon, M.I. 1992. Methods In Enzymology. Academic Press Limited, $3: 213$

Britto, G., Jensen, L.S., Pfander, H. 1995. Caratenoids. Volume 1B Spectroscopy. Pengamon Press. University of Liverpool United Kindom.

Britton, G. 1995. Carotenoids. Isolation and analysis. Vol 1 A. Britton G. Jensen S.L., Pafander, H. 2004. Carotenoids (Handbook) Pengamon Press. University of Liverpool United Kindom

Landrum, J.T. 2010. Carotenoids Physical, Chemical, and Biological Fuction and Properties. CRC Press. New York.

Marthen, P.I., Bennet. 1993. A Coral Reef Hand Book: A Guide To The Geology, Flora And Fauna Of The Great Barrier Reef. Published by surrey beatty sons pty limited Australia.

Majchacheep, S. 1989. Marine Animal Of Thailand. Published By Prae Pittaya. Thailand.

Mantiri, D.M.H., Nègre-Sadargues, G. Charmantier., Trilles J.C., Milicua G.R., 
Castillo. 1996. Nature and Metabolism of Carotenoid Pigments during the Embryogenesis of the European Lobster Homarus gammarus (Linne, 1758). Journal of Comparative Biochemistry and Physiology, 3 (115) : 237-241.

Mantiri, D.H.M. 1997. These. Nature, Localization et Metabolisme des Cartenoides et des Complexes Caratenoproteiques au Cours de L'Evolution Embryonnaire et Larvaire du Hommard Europeen Hsomarus gammarus. Universite De Droit, D' Economie et des Sciences D' Aix Marseille.

Mantiri, D.M.H., Nègre-Sadargues, G., Milicua J.C.G., Castillo, R. 2004. The Carotenoproteins During Embryogenesis and Larval Development of the European Lobster Homarus Gammarus. Journal of Crustacean Biology, 24 (4) : 592-602

Makalalag, S., Paransa J.S.D., Mantiri, D.M.H. 2017. Penentuan Kandungan Pigmen Karetenoid pada Kepiting Grapsus albolineatus (Lamarck) Betina dari Perairan pesisir Pantai Tanawangko. Jurnal pesisir dan Laut Tropis, 3 (1) :1-9

Paransa, D.S.J., Mantiri, D.M.H., Korompis, F. 2002. Penentuan Kandungan Pigmen Karotenoid Pada Kepiting Grapsus alboneatus (lamarck) Betina Berdasarkan Beda Larutan Pengembang Pada Kromatografi Lapis Tipis. Jurnal Perikanan dan IImu Kelautan, 1 (3) : 1 - 10.

Paransa, D.S.J. 2005. Pemurnian Jenis Pigmen Karotenoid Pada Kepiting Grapsus albolineatus (Lamarck) Jantan. Jurnal Warta - Wiptek Fakultas Perikanan dan IImu Kelautan UNSRAT Manado.

Paransa, D.S.J., Abdullah, Z. 2007. Isolasi Pigmen Karotenoid Pada Ekstrak Kepiting Bakau Scylla serrata. Jurnal Warta- Wiptek.

Rohman, A. 2009. Kormatografi untuk Analisis Obat. Edisi Pertama-Graha IImu.
Stahl, E. 1985. Analisis Obat Secara Kormatografi dan Mikroskopi. Penerbit ITB Jl. Genesa Bandung.

Thamin A. Umar C. Paransa, D.S.J. 2006. Analisis Pigmen dan Aktivitas Antibakteri In Vitro Pigmen Astaksantin Kepiting Grapsus albolineatus Lamarck Jantan. Jurnal Perikanan, 8(2):1-8.

Wowaruntu, Eva S. 2003. Isolasi Ekstrak Pigmen Xantofil Pada Lapisan Epidermis Kepiting Grapsus albolineatus (Lamarck) Jantan Menggunakan Prinsip Saponifikasi. Skripsi. Fakultas Perikanan dan IImu Kelautan UNSRAT Manado. 